
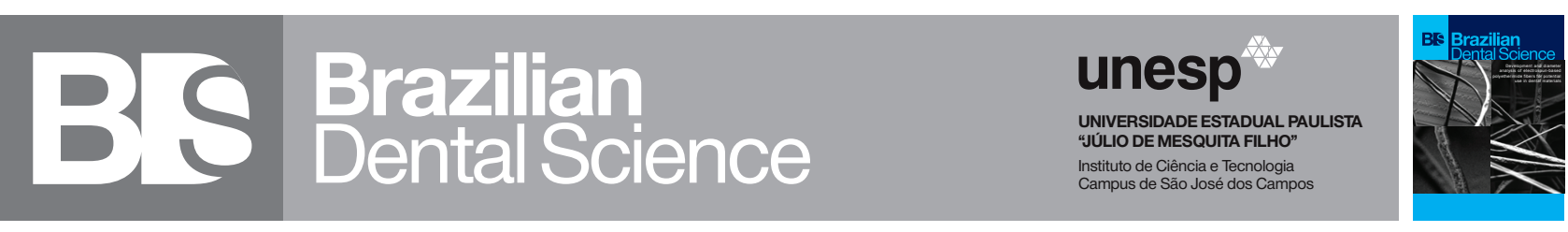

\title{
Inferior alveolar nerve paraesthesia after overfilling into the mandibular canal, confirmed by cone-beam computed tomography: a case report
}

Parestesia do nervo alveolar inferior após extravasamento de material obturador para o canal mandibular, confirmado por meio da tomografia computadorizada de feixe cônico: relato de caso

Claudemir de SOUZA JÚNIOR ${ }^{1}$, Ricardo MACHADO $^{2}$, Renee Ashley BATTS ${ }^{3}$, Lucas da Fonseca Roberti GARCIA ${ }^{3}$

1 - Paranaense University - UNIPAR, Francisco Beltrão, Paraná, Brazil.

2 - Clinical Practice Limited to Endodontics, Navegantes, Santa Catarina, Brazil.

3 - Department of Dentistry - Endodontics Division, Health Sciences Center, Federal University of Santa Catarina, Florianópolis, Santa Catarina, Brazil.

\begin{abstract}
The filling material should be restricted to the root canal, and not extend to the periradicular tissues. Overextension occurs when there is an overflow of gutta-percha and sealer, whereas overfilling refers to the overflow only of sealer beyond the apical foramen. Both may cause several negative clinical consequences. Nevertheless, an accurate diagnosis of where they occurred cannot always be performed by conventional radiographic examination, because of the two-dimensional aspect of the image. This paper describes a clinical case of labiomandibular paraesthesia after overfilling into the mandibular canal (MC), as diagnosed by cone-beam computed tomography (CBCT), later used to perform the treatment planning. A 34-year-old Caucasian female patient sought a private dental clinic complaining of pain in the right mandibular posterior region. After taking the anamnesis and performing clinical and radiographic exams, the patient was diagnosed with pulp necrosis in the second right mandibular molar, and underwent root canal treatment. The final radiography showed overextension or overfilling, probably into the MC. About 2 hours after the procedure, the patient reported paraesthesia of her lower right lip and chin. A CBCT confirmed a small overfilling into the MC. For this reason, vitamin B12 was prescribed as the first treatment option. After 7 days, the patient reported a significant decrease in paraesthesia, and was completely normal after 15 days. This case report shows that CBCT is an effective radiographic diagnostic tool that can be used as an alternative in clinical cases of labiomandibular paraesthesia caused by overextension or overfilling.
\end{abstract}

\section{KEYWORDS}

Endodontic treatment; Overfilling; Paraesthesia; Conebeam computed tomography.

\section{RESUMO}

O material obturador deve preencher todo o canal sem extravasar para os tecidos perirradiculares. O extravasamento de guta-percha e cimento além do forame apical, denomina-se sobrextensão, enquanto o termo sobreobturação refere-se ao extravasamento de cimento endodôntico. Ambos podem causar consequências clínicas negativas, porém um preciso diagnóstico nem sempre é logrado somente a partir do exame radiográfico convencional em razão de sua natureza bidimensional. O presente relato descreve um caso clínico de parestesia de lábio inferior e mento após o extravasamento de cimento obturador para o canal mandibular (CM), diagnosticado por meio da tomografia computadorizada de feixe cônico (TCFC), também utilizada para o planejamento do tratamento. Paciente do gênero feminino, 34 anos, leucoderma, procurou atendimento odontológico particular queixando-se de dor odontogênica na região posterior direita da mandíbula. Finalizados a anamnese e o exame clínico-radiográfico, diagnosticou-se a necrose pulpar do segundo molar inferior direito, ulteriormente submetido ao tratamento endodôntico. A radiografia final evidenciou provável extravasamento de material obturador para o interior do CM. Aproximadamente 2 horas após, a paciente relatou parestesia no lábio inferior direito e no queixo, e a TCFC confirmou a presença de pequena quantidade de cimento obturador no CM. Por conseguinte, a prescrição de vitamina B12 foi o tratamento de escolha. Decorridos 7 dias, a paciente referiu significativa diminuição da parestesia e após 15 dias os padrões de normalidade estavam completamente restabelecidos. O presente relato de caso demonstra que a TCFC é uma ferramenta de diagnóstico potencialmente empregada em casos de parestesia labiomandibular causada por sobrextensão ou sobreobturação.

\section{PALAVRAS-CHAVE}

Tratamento endodôntico; Sobreobturação; Parestesia; Tomografia computadorizada de feixe cônico. 


\section{INTRODUCTION}

7 ndodontic treatment is performed mainly 1 to restore and maintain the health of periradicular tissues, by ensuring cleaning and filling of the root canal system $[1,2]$. The septic content of this system cannot be completely eliminated merely by chemomechanical preparation, with or without intracanal dressing [3]. Therefore, effective filling is vital to ensure long-term success of the endodontic treatment [3]. The obturation must be performed correctly to keep the canal clean, following chemomechanical preparation and intracanal dressing (when used). This will ensure entrapment of the remaining microorganisms and interruption of the supply of nutrients needed for their survival [1].

It is crucial that the filling material not extend beyond the main root canal to periapical tissues or other adjacent structures [4]. Overextension occurs when there is an overflow of gutta-percha and sealer, whereas overfilling refers to the overflow only of sealer beyond the apical foramen Both may cause several adverse clinical consequences $[5,6]$. When overextension or overfilling occurs in mandibular posterior teeth, the inferior alveolar nerve may be damaged, commonly leading to labiomandibular paraesthesia $[5,6]$. Several clinical cases have been published reporting their occurrence in mandibular second molars, although there have also been cases affecting first molars and premolars [6].

In cases of overextension and overfilling, conventional radiographic examinations may not always be able to accurately diagnose where it occurred [5], because they provide only images with two-dimensional aspects [7]. Cone-beam computed tomography (CBCT) is a much more accurate exam, because it allows the analysis of areas of interest in different planes (coronal, sagittal and transversal) [8].

This paper describes a clinical case of labiomandibular paraesthesia after overfilling into the mandibular canal (MC), as diagnosed by CBCT, later used to perform the treatment planning.

\section{CASE REPORT}

A 34-year-old Caucasian female patient sought a private dental clinic complaining of pain in the right mandibular posterior region. During the anamnesis, the patient complained of pain occurring spontaneously after receiving a single dental implant in the right mandibular posterior region, and undergoing a restorative procedure a couple of years prior.

The clinical examination revealed a prosthetic crown and an occlusal restoration in composite resin in the first and second right mandibular molars, respectively. The premolars were sound. Vertical percussion resulted in pain to the second right mandibular molar, but horizontal percussion caused no symptoms. Neither of the tests caused sensitivity-induced pain in the first right mandibular molar. There was physiological mobility in the teeth mentioned above. The second right mandibular molar showed no response to the cold test. A small thickening of the periodontal ligament of the roots of the second right mandibular molar was observed in the radiographic examination. An implant supported the prosthetic crown of the first right mandibular molar, with no observable abnormality. In addition, the apexes of the roots of the second right mandibular molar overlapped the MC (Figure 1A). The clinical findings suggested pulp necrosis in the second right mandibular molar. The procedure indicated for this diagnosis was root canal treatment.

Following anesthesia (2\% Mepiadre 1:100.000, Nova DFL, Rio de Janeiro, RJ, Brazil) and rubber dam isolation, the coronal opening was performed by using no. 1016 and Endo-Z drills (KG Sorensen, Barueri, SP, Brazil). Three root canals were located, two in the mesial 
and one in the distal root. Their openings were prepared with sizes 1 (mesial) and 2 (distal) Largo drills. The cervical and middle thirds were prepared with a 0.30/10 ProDesign S file (Easy Equipamentos Odontológicos, Belo Horizonte, MG, Brazil), after initial negotiation of the root canals with sizes 10 and 15 K-type files (Dentsply, Konstanz, Germany). The working length of each root canal was then determined in the apical foramen $[9,10]$ with an electronic apex locator (DPEX, MicroImagem, São Paulo, SP, Brazil). Chemomechanical preparation was performed with the ProDesign S system (Easy Equipamentos Odontológicos) up to the $0.25 / 06$ file. Five $\mathrm{mL}$ of $2.5 \%$ sodium hypochlorite $(\mathrm{NaOCl})$ solution (Biodinâmica, Ibiporã, PR, Brazil) was used for root canal irrigation, at each file change.

The chemomechanical preparation was followed by flooding of the root canals, interleaving $2.5 \% \mathrm{NaOCl}$ solution with $17 \%$ EDTA (Biodinâmica). A plastic point (Easy Clean, Easy Equipamentos Odontológicos) [11] was used for mechanical agitation of both solutions. Afterwards, the root canals were dried with sterile absorbent paper points.

After radiographic master cones analysis (Figure 1B), the root canals were filled with $\mathrm{AH}$ Plus sealer (Dentsply, Konstanz, Germany), using Tagger's Hybrid technique. The pulp chamber was then cleaned, and the tooth was sealed temporarily (Bulk Fill Composite, FGM, Joinville, SC, Brazil). The final radiography showed overextension or overfilling, probably into the MC (Figure 1C). About 2 hours after the procedure, the patient reported paraesthesia of her lower right lip and chin. A CBCT confirmed a small overfilling into the MC (Figures 2, 3 and 4). For this reason, vitamin B12 was prescribed as the first treatment option [12]. After 7 days, the patient reported a significant decrease in paraesthesia, and was completely normal after 15 days (Figure 5A). After 12 months the patient returned for a follow-up visit, and the tooth continued to be free of symptoms and was completely functional (Figure 5B).

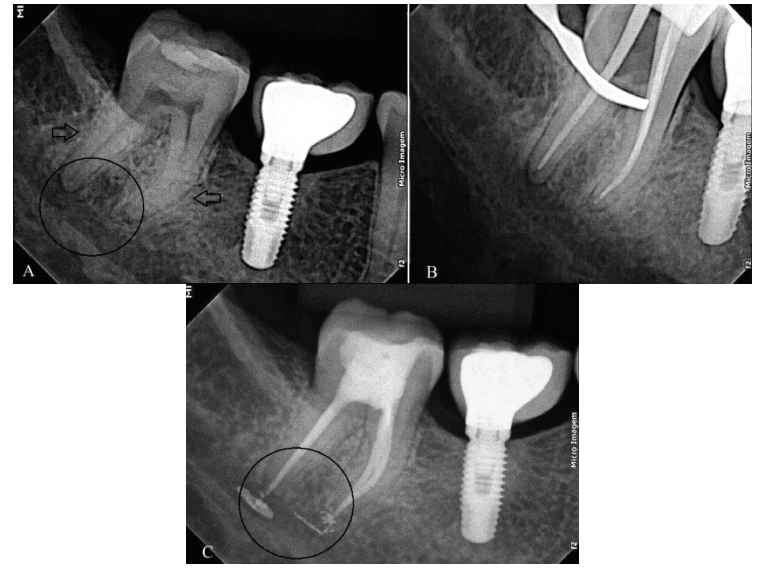

Figure 1 - A) Initial periapical radiograph of the first and second right lower molar region. Prosthetic crown on the first molar, supported by a titanium implant with apparently adequate bone integration. In the second molar, a slight thickening of the periodontal ligament (arrows) can be observed, but with no radiolucent area suggesting periapical lesion in the root apex. Radiopaque imaging was also observed on the occlusal surface, suggesting a clinically confirmed composite resin restoration. Note the overlapping of the mesial and distal roots of the lower second molar with the MC (circle). B) Proof of the master guttapercha cone before root canal filling. Both cones ran the full length of the root canal, reaching their working length $(1 \mathrm{~mm}$ short of the root apex), and locking on it. C) Final periapical radiograph demonstrating the extrusion of the root canal sealer into the MC (circle).

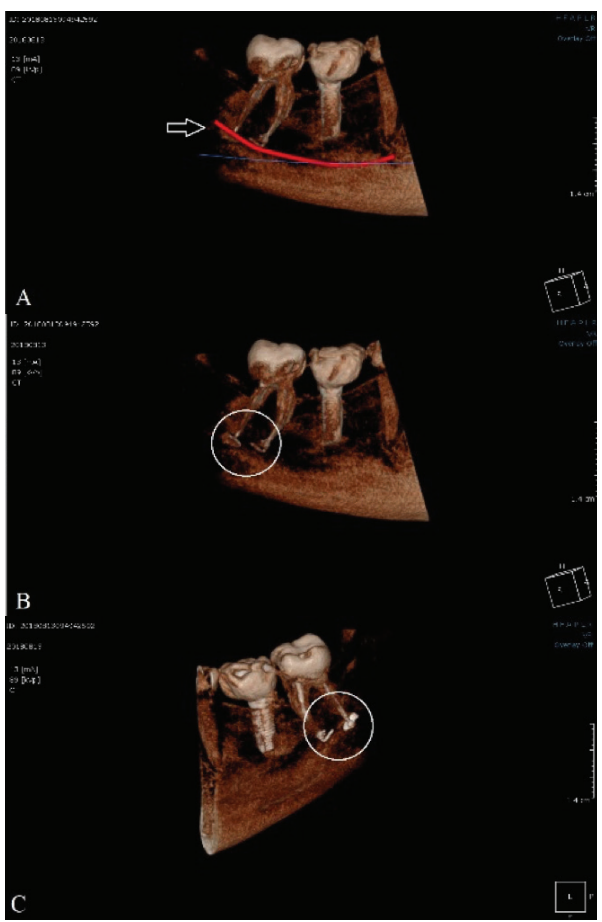

Figure 2 - 3D tomographic reconstruction of the right lower first and second molar region. A) Red line overlapping the area corresponding to the $\mathrm{MC}$. Note the close relationship of this anatomical structure with the apex of the distal and mesial roots of the right lower second molar (arrow). B) and C) Root canal sealer extruded from the apical foramen of the distal and mesial roots into the $\mathrm{MC}$ (circle). 


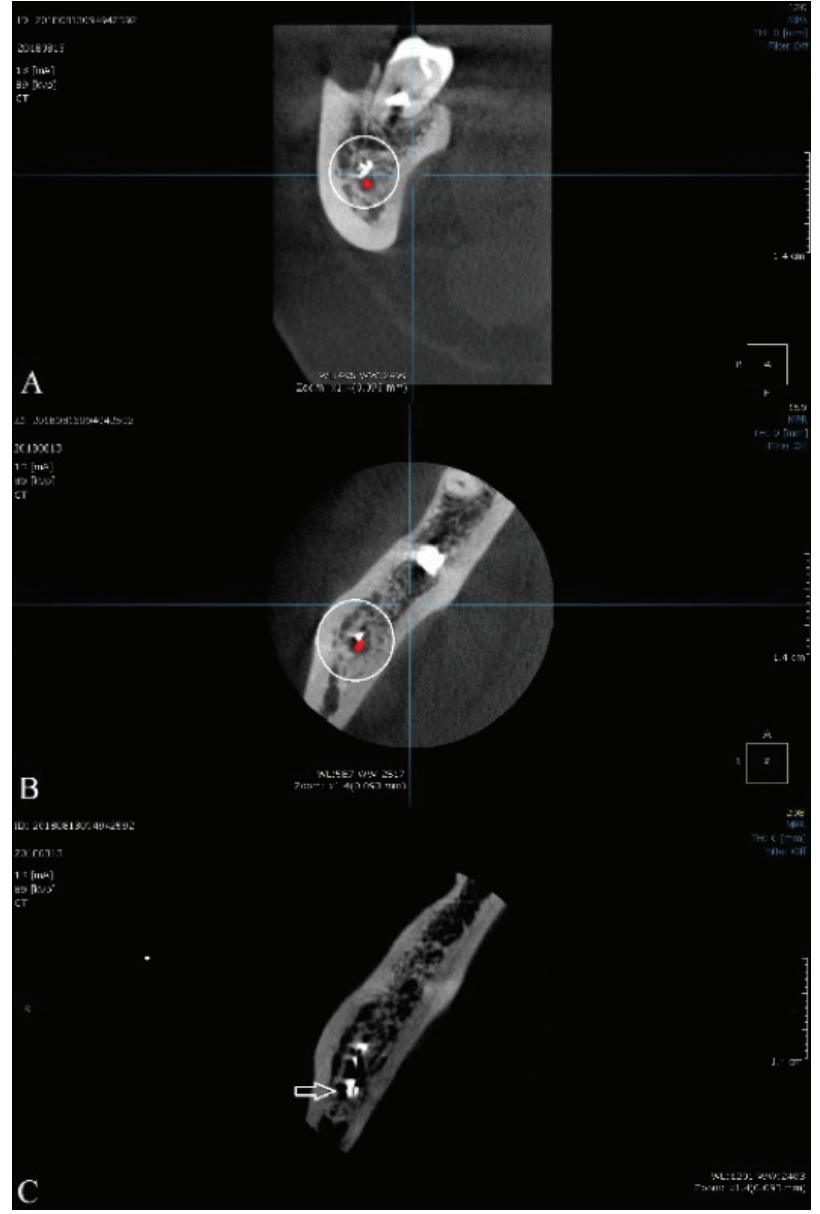

Figure 3 - A) Tomographic section in the coronal direction, showing the mandibular canal (red point) with root canal sealer inside the canal (circle). B) Axial tomographic section. Area corresponding to the $\mathrm{MC}$ (red point), with root canal sealer inside (circle). C) Presence of root canal sealer inside the MC (arrow).

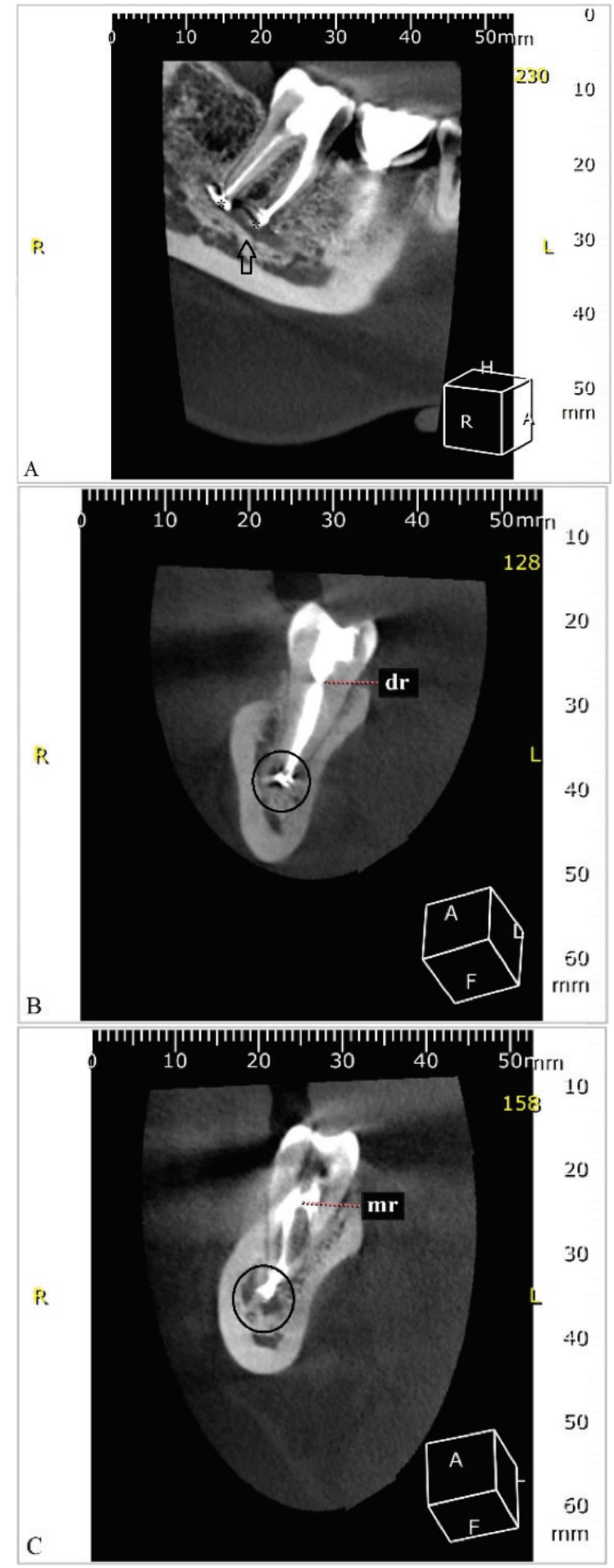

Figure 4 - A) Sagittal tomographic section. Image of the area corresponding to the MC (arrow), with extruded root canal sealer inside $\left(^{\star}\right)$. B) Coronal tomographic section (distal root - dr). Note the presence of root canal sealer inside the MC (circle). C) Coronal tomographic section (mesial root - mr). Less root canal sealer inside the MC (circle). 


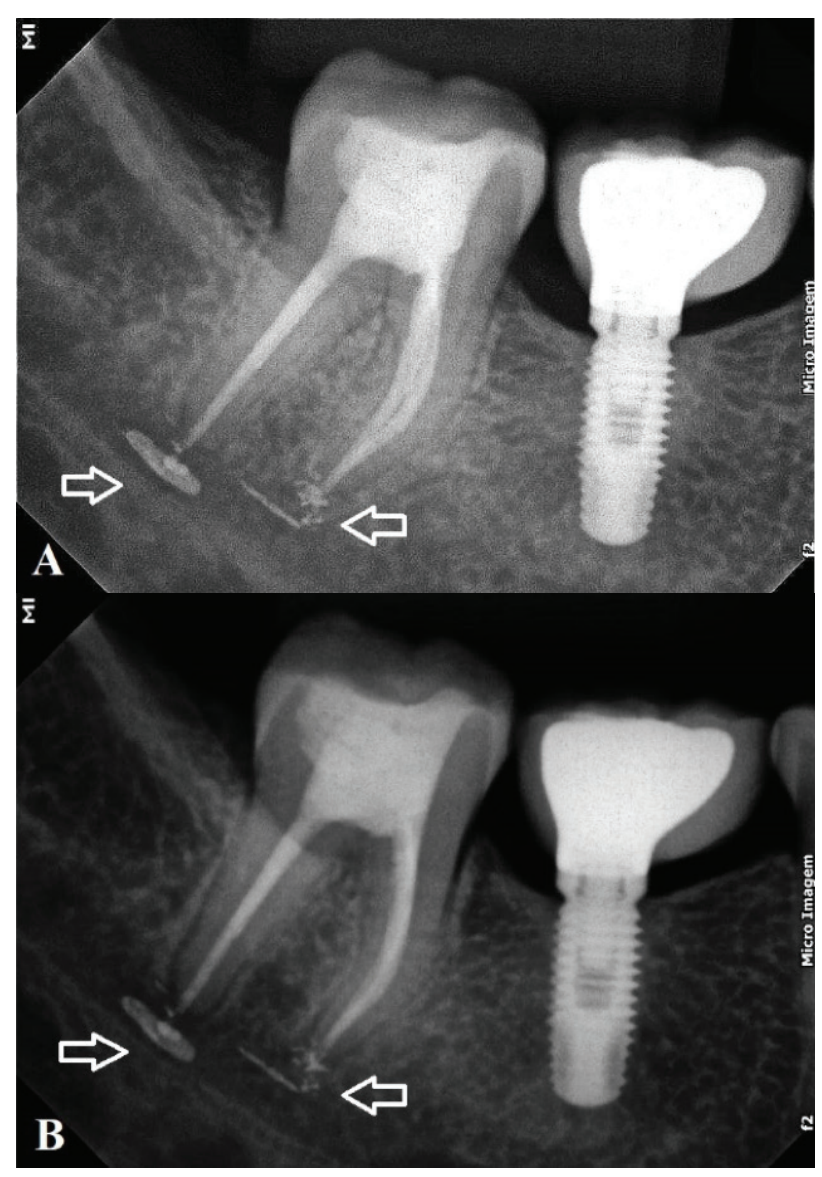

Figure $\mathbf{5}$ - Periapical radiographs of postoperative control of the right first and second lower molar region. A) 15 days; and B) 12 months. Presence of root canal sealer inside the MC (arrows) in both images. However, signs of inferior alveolar nerve paraesthesia had disappeared completely within 15 days.

\section{DISCUSSION}

Endodontic treatment is performed mainly to restore and maintain the health of periradicular tissues, by ensuring cleaning and filling of the root canal system [1,2]. Obturation is responsible for maintaining this system clean after preliminary procedures, entrapment of the remaining microorganisms, and interruption of the supply of nutrients needed for their survival [1]. Extrusion of the filling material beyond the apical foramen may cause several adverse clinical consequences $[5,6]$. Overextension or overfilling in mandibular posterior teeth, may cause damage to the inferior alveolar nerve, leading to labiomandibular paraesthesia [5,
6]. Conventional radiographic examinations may not always be able to accurately diagnose either situation, because they provide images with only two-dimensional aspects [7]. The aim of this paper was to describe a clinical case of labiomandibular paraesthesia after overfilling into the $\mathrm{MC}$, as diagnosed by CBCT, later used to perform the treatment planning.

The anatomical complexity of the root canal system makes adequate cleaning and shaping difficult, especially in the apical thirds of the root $[13,14]$. In some cases, endodontic infection extends beyond the limits of apical constriction, to the apical foramen or beyond (extraradical biofilm) [15]. Intentional foraminal enlargement (overinstrumentation) may be performed in these cases to decrease the microbial contingent to levels more favorable for repair [16]. Previous studies showed that this procedure presented encouraging results, probably because of the more efficient mechanical action of instruments and chemical action of irrigating solutions in this region $[17,18]$. However, Hulsmann \& Hahn [19] showed that greater enlargement of the apical foramen poses the risk of extrusion of any substance or material used in the root canal.

Paraesthesia is a permanent or episodic sensation of ticking, prickling, or tingling of the lower lip [20]. It has been reported to occur during and after root canal treatment of both mandibular premolars [21] and molars [22]. It is uncertain if the paraesthesia of the present case was caused by overinstrumentation or overfilling, considering that the treatment was performed in a single visit. However, overinstrumentation may be considered as a transient aggression to the neural structures near the apex. On the other hand, overfilling may be a permanent aggression, especially when a non-resorbable endodontic sealer such as $\mathrm{AH}$ Plus is used. In this case report, paraesthesia was caused by overfilling, as a consequence of the intentional foraminal enlargement [19]. 
CBCT has several advantages over conventional radiographs, mostly because it can more readily obtain additional information on root canal morphology and adjacent anatomical structures (e.g. the maxillary sinus and mandibular nerve), on the real nature and relationship of a periapical lesion to a root, and on the thickness of the cortical and cancellous plates [23]. These distinctions have recently led CBCT to gain popularity among endodontic specialists. Oliveira et al. [24] investigated the distance between the root apices of posterior teeth and the MC, and the bone density in such areas. A private oral radiology clinic database provided one thousand randomly selected retrospective CBCT scans. The images were acquired with a limited field of view and analyzed by 2 examiners who measured the shortest distance between the root apices and the upper cortical bone of the MC using Dental Slice software. The "profile line of Hounsfield" tool was used to determine bone density, which was expressed in Hounsfield units. The distal root of the right second mandibular molars was the closest to the MC (mean $=3.41 \mathrm{~mm}$ ), and the right first mandibular premolar root was the farthest from the MC (mean $=5.87 \mathrm{~mm}$ ), respectively. The root apices were closer to the $\mathrm{MC}$ in women than in men $(\mathrm{P}<.05)$ The roots were in contact with or invaded the MC in 1.79\% of the cases, whereas $8.35 \%$ of the root apices were close to the MC $(<1.00 \mathrm{~mm})$, and $89.85 \%$ were far from the MC $(>1.00 \mathrm{~mm})$. Bone density was high in $85.55 \%$ of the cases. The results suggest that the risk of damage to the inferior alveolar nerve is higher for second mandibular molars, especially in female patients. The present case report involved a woman patient, and the overfill invaded the MC through the distal canal of a second mandibular molar.

AH Plus was used in this case report, because it is considered the gold standard among endodontic sealers. The monomer 2,2-bis[4-(2hydroxy-3-methacrylyloxypropoxy) phenyl]- propane (BisGMA), prepared from bisphenol A and glycidyl methacrylate, is the major ingredient of epoxy resin-based root canal sealers AH 26 and AH Plus [25]. The curing power of AH 26 is attributed to its generation of formaldehyde as a by-product; however, AH Plus only releases small amounts of formaldehyde [26]. On the other hand, negative aspects of AH Plus include possible cytotoxic effects [27] when extruded into the MC [28]. Its bisphenol A component may also promote cytotoxic effects [29]. In this case report, the amount of sealer was small; this was considered as a positive prognostic factor [5]. Consequently, we decided in favor of just prescribing vitamin B12 for paraesthesia treatment [12].

A meta-analysis performed by Peng et al. [30] demonstrated that a greater incidence of overextension was observed in warm guttapercha obturation techniques compared with the cold lateral condensation. Moreover, $\mathrm{AH}$ Plus sealer has shown greater flow index than several others endodontic sealers [31]. In this case report, both the filling technique (Tagger's Hybrid) and the sealer (AH Plus) used predicted the overfilling.

Even considering that the patient totally recovered her sensitivity after 15 days, this clinical case reiterates the danger of extruded materials during root canal treatment, especially if they come close to important anatomical areas [5]. CBCT examination prior to treatment may have helped to establish a better treatment plan, by preventing extrusion of the filling material, and consequent paraesthesia.

\section{CONCLUSION}

CBCT is an effective radiographic diagnostic tool that can be used as an alternative in clinical cases of paraesthesia caused by overextension or overfilling. This negative consequence may be prevented by requesting a CBCT exam before initiating endodontic treatment. 


\section{Conflict of Interest}

There is no conflict of interest in this case report.

\section{REFERENCES}

1. Schilder H. Filling root canals in three dimensions. Dent Clin North Am. 1967:723-44.

2. Schilder H. Cleaning and shaping the root canal. Dent Clin North Am. 1974:18(2):269-96

3. Adl A, Motamedifar M, Shams MS, Mirzaie A. Clinical investigation of the effect of calcium hydroxide intracanal dressing on bacterial lipopolysaccharide reduction from infected root canals. Aust Endod J. 2015 Apr;41(1):12-6. doi: 10.1111/aej.12054. Epub2013 Dec 13. PMID: 24330326.

4. Schaeffer MA, White RR, Walton RE. Determining the optimal obturation length: a meta-analysis of literature. J Endod. $2005 \mathrm{Apr} ; 31(4): 271-4$. doi: 10.1097/01.don.0000140585.52178.78.PMID: 15793382

5. Gambarini G, Plotino G, Grande NM, Testarelli L, Prencipe M, Messineo D, Fratini L, D'Ambrosio F. Differential diagnosis of endodontic-related inferior alveolar nerve paraesthesia with cone beam computed tomography: a case report. Int Endod J. 2011 Feb;44(2):176-81. doi: 10.1111/j.1365-2591.2010.01816.X Epub 2010 Nov 17.PMID: 21083573

6. Knowles KI, Jergenson MA, Howard JH. Paresthesia associated with endodontic treatment of mandibular premolars. J Endod. 2003 Nov;29(11):768-70. doi: 101097/00004770-200311000-00019. PMID: 14651287.

7. Patel S, Brown J, Pimentel T, Kelly RD, Abella F, Durack C. Cone beam computed tomography in Endodontics - a review of the literature. Int Endod J. 2019 Aug;52(8):1138-1152. doi: 10.1111/iej.13115. Epub2019 Apr 9. PMID: 30868610 .

8. Martins JNR, Alkhawas MAM, Altaki Z, Bellardini G, Berti L, Boveda C, et al. Worldwide Analyses of Maxillary First Molar Second Mesiobuccal Prevalence: A Multicenter Cone-beam Computed Tomographic Study. J Endod. 2018 Nov;44(11):1641-1649.e1. doi: 10.1016/j.joen.2018.07.027. Epub 2018 Sep 19. PMID: 30243661.

9. Yaylali IE, Teke A, Tunca YM. The Effect of Foraminal Enlargement of Necrotic Teeth with a Continuous Rotary System on Postoperative Pain: A Randomized Controlled Trial. JEndod. 2017 Mar;43(3):359-363. doi: 10.1016/j. joen.2016.11.009. PMID: 28231975

10. Saini HR, Sangwan P, Sangwan A. Pain following foraminal enlargement in mandibular molars with necrosis and apical periodontitis: A randomized controlled trial. IntEndod J. 2016 Dec;49(12):1116-1123. doi: 10.1111/iej.12583. Epub2015 Dec 23. PMID: 26580483.

11. Marques AC, Aguiar BA, Frota LM, Guimarães BM, Vivacqua-Gomes N. Vivan RR, Duarte MA, de Vasconcelos BC. Evaluation of Influence of Widening Apical Preparation of Root Canals on Efficiency of Ethylenediaminetetraacetic Acid Agitation Protocols: Study by Scanning Electron Microscopy. J Contemp Dent Pract. 2018 Sep 1;19(9):1087-1094. PMID: 30287709.

12. Yatsuhashi T, Nakagawa K, Matsumoto M, Kasahara M, Igarashi T, Ichinohe T, Kaneko Y. Inferior alveolar nerve paresthesia relieved by microscopic endodontic treatment. Bull Tokyo Dent Coll. 2003 Nov:44(4):209-12. doi: 10.2209/tdcpublication.44.209.PMID: 15103918
13. Paqué F, GanahID, Peters OA. Effects of root canal preparation on apical geometry assessed by micro-computed tomography. JEndod. 2009 Jul;35(7):1056-9. doi:10.1016/j.joen.2009.04.020. PMID: 19567334

14. Paqué F, Balmer M, Attin T,Peters OA. Preparation of oval-shaped root canals in mandibular molars using nickel-titanium rotary instruments: a microcomputed tomography study. JEndod. 2010 Apr;36(4):703-7. doi: 101016/j. joen.2009.12.020. PMID: 20307747

15. Chavez de Paz LE. Redefining the persistent infection in root canals: possible role of biofilm communities. J Endod. 2007 Jun;33(6):652-62. doi: 10.1016/j.joen.2006.11.004. Epub 2007 Mar 23. Erratum in: J Endod. 2007 Nov;33(11):1289. Chávez de Paz, Luis [corrected to Chavez de Paz, Luis E]. PMID: 17509401.

16. Borlina SC, de Souza V, Holland R, Murata SS, Gomes-Filho JE, Dezan Junior E, Marion JJ, Neto Ddos A. Influence of apical foramen widening and sealer on the healing of chronic periapical lesions induced in dogs' teeth. Oral Surg Oral Med Oral Pathol Oral Radiol Endod. 2010 Jun;109(6):932-40. doi: 10.1016/j.triple0.2010.01.028. PMID: 20451847.

17. Card SJ, Sigurdsson A, Orstavik D, Trope M. The effectiveness of increased apical enlargement in reducing intracanal bacteria. J Endod. 2002 Nov;28(11):779-83. doi:10.1097/00004770-200211000-00008.PMID: 12470024.

18. de Souza Filho FJ, Benatti 0, de Almeida OP. Influence of the enlargement of the apical foramen in periapical repair of contaminated teeth of dog. Oral Surg Oral Med Oral Pathol. 1987 0ct;64(4):480-4. doi:101016/00304220(87)90157-5. PMID:3477772

19. Hülsmann $M$, Hahn W. Complications during root canal irrigation--literature review and case reports. Int Endod J. 2000 May;33(3):186-93. doi: 10.1046/j.1365-2591.2000.00303.x. PMID: 11307434.

20. Di Lenarda R, Cadenaro M, Stacchi C. Paresthesia of the mental nerve induced by periapical infection: a case report. Oral Surg Oral Med Oral Pathol Oral Radiol Endod. 2000 Dec;90(6):746-9. doi: 10.1067/moe.2000.110418. PMID: 11113821

21. Giuliani M, Lajolo C, Deli G, Silveri C. Inferior alveolar nerve paresthesia caused by endodontic pathosis: a case report and review of the literature. Oral Surg Oral Med Oral Pathol Oral Radiol Endod. 2001Dec;92(6):670-4. doi: 10.1067/moe.2001.117269. PMID: 11740484

22. Antrim DD. Paresthesia of the inferior alveolar nerve caused by periapical pathology. J Endod. 1978 Jul;4(7):220-1. doi: 10.1016/S0099-2399(78)801873. PMID:283186.

23. Low KM, Dula K, Bürgin W, von Arx T. Comparison of periapical radiography and limited cone-beam tomography in posterior maxillary teeth referred for apical surgery. J Endod. 2008 May;34(5):557-62. doi: 101016/j. joen.2008.02.022. PMID: 18436034.

24. Oliveira ACS, Candeiro GTM, Pacheco da CostaFFN, Gazzaneo ID, Alves FRF, Marques FV. Distance and Bone Density between the Root Apex and the Mandibular Canal: A Cone-beam Study of 9202 Roots from a Brazilian Population. J Endod. 2019 May;45(5):538-542.e2. doi: 10.1016/j. joen.2019.01.004. Epub 2019 Mar 23. PMID: 30910355.

25. Peutzfeldt A. Resin composites in dentistry: the monomer systems. Eur J Oral Sci. 1997 Apr;105(2):97-116. doi: 10.1111/j.1600-0722.1997.tb00188.x. PMID: 9151062.

26. Leonardo MR, Bezerra da Silva LA, Filho MT, Santana da Silva R. Release of formaldehyde by 4 endodontic sealers. Oral Surg Oral Med Oral Pathol Oral Radiol Endod. 1999 Aug;88(2):221-5. doi: 101016/s1079-2104(99)70119-8. PMID: 10468467 
27. Pulgar R, Segura-Egea JJ, Fernández MF, Serna A, Olea N. The effect of AH 26 and AH Plus on MCF-7 breast cancer cell proliferation in vitro. Int Endod J. 2002 Jun;35(6):551-6. doi: 10.1046/j.1365-2591.2002.00531.x. PMID: 12190913.

28. Tamse A, Kaffe I, Littner MM, Kozlovsky A. Paresthesia following overextension of AH-26: report of two cases and review of the literature. Endod. 1982 Feb;8(2):88-90. doi: 10.1016/S0099-2399(82)80265-3. PMID: 7038020.

29. Segura JJ, Jiménez-Rubio A, Pulgar R, Olea N, Guerrero JM, Calvo JR. In vitro effect of the resin component bisphenol $A$ on substrate adherence capacity of macrophages. J Endod. 1999 May;25(5):341-4. doi:10.1016/S00992399(06)81168-4. PMID: 10530258.
30. Peng L Ye L Tan H, Zhou X Outcome of root canal obturation by warm gutta-percha versus cold lateral condensation: a meta-analysis. J Endod. 2007 Feb;33(2):106-9. doi: 10.1016/.j.joen.2006.09.010. Epub 2006 Dec 22. PMID: 17258624.

31. Shakya VK, Gupta P, Tikku AP, Pathak AK, Chandra A, Yadav RK, Bhart $\mathrm{R}$, Singh RK. An Invitro Evaluation of Antimicrobial Efficacy and Flow Characteristics for AH Plus, MTA Fillapex, CRCS and Gutta Flow 2 Root Canal Sealer. J Clin Diagn Res. 2016 Aug;10(8):ZC104-8. doi:10.7860/ JCDR/2016/20885.8351. Epub 2016 Aug 1.PMID:27656550; PMCID: PMC5028590

\section{Ricardo Machado}

\section{(Corresponding address)}

Rua Brasília, 300, Apto. 503, Ed. Vila dos Ipês, Centro, Navegantes,

Santa Catarina, CEP. 88.300-100, Brazil

Email: ricardo.machado.endo@gmail.com

Date submitted: 2020 Jul 27

Accept submission: 2020 0ct 12 